\title{
LAJU FILTRASI GLOMERULUS PASIEN DIABETES MELITUS TIPE II DI SALAH SATU RUMAH SAKIT SWASTA DI KABUPATEN DEMAK
}

\author{
Fef Rukminingsih ${ }^{1}$, Mei Widiastuti ${ }^{2}$ \\ ${ }^{1,2}$ Politeknik Katolik Mangunwijaya
}

Email korespondensi : fefrukminingsih@gmail.com

\begin{abstract}
ABSTRAK
Diabetes Melitus (DM) Tipe II merupakan kelompok penyakit metabolik dengan karakteristik hiperglikemia. Penggunaan obat hipoglikemik oral $(\mathrm{OHO})$ berlangsung dalam waktu yang relative lama. Sebagian besar OHO di ekskresi melalui ginjal. Penelitian ini bertujuan untuk mengetahui Laju Filtrasi Glomerulus (LFG) pasien DM tipe 2 yang menggunakan $\mathrm{OHO}$ di salah satu rumah sakit swasta di Kabupaten Demak. Penelitian ini merupakan penelitian deskriptif observasional menggunakan data retrospektif yang diperoleh dari data rekam medis (RM) pasien rawat jalan peserta JKN dengan DM tipe 2 periode Oktober-Desember 2020. Kriteria inklusi adalah pasien yang mendapat terapi OHO minimal satu tahun dengan atau tanpa penyakit penyerta, berumur 36 - 65 tahun, dan mempunyai pemeriksaan serum kreatinin. Pasien yang mendapat terapi kombinasi dengan insulin di ekslusi. LFG dihitung menggunakan rumus dari Cockroft-Gault. Dari 82 pasien diketahui 52 pasien $(62,2 \%)$ berjenis kelamin perempuan, sebanyak 74 pasien $(90,2 \%)$ berumur lebih dari 45 tahun. Pasien yang mengkonsumsi OHO lebih dari 2 tahun sebanyak 47 (57,3\%). Pasien tanpa penyakit penyerta sebanyak $62(75,7 \%)$ orang. Pasien yang mengalami penurunan LFG kategori sedang (stage 3) sebanyak 24 orang (29,3\%), penurunan LFG kategori berat (stage 4) sebanyak 5 orang $(6,1 \%)$ dan 1 orang $(1,2 \%)$ mengalami End Stage Renal Disease.
\end{abstract}

Kata kunci : Laju Filtrasi Glomerulus, DM Tipe II, Peserta JKN 


\title{
GLOMERULUS FILTRATION RATE OF TYPE II DIABETES MELLITUS PATIENTS IN A PRIVATE HOSPITAL IN DEMAK DISTRICT
}

\begin{abstract}
Diabetes Mellitus (DM) Type II is a group of metabolic diseases with hyperglycemia characteristics. The use of oral hypoglycemic medicine (OHM) lasts for a relatively long time. Most of the OHM is excreted through the kidneys. This study aims to determine the Glomerulus Filtration Rate (GFR) of type 2 DM patients who use OHM in a private hospital in Demak District. This study is an observational descriptive study using retrospective data obtained from medical record data (MR) of outpatient JKN participants with type 2 DM for the period October-December 2020. Inclusion criteria were patients who received OHM therapy for at least one year with or without comorbidities, aged 36-65 years, and had a serum creatinine test. Patients receiving combination therapy with insulin were excluded. LFG is calculated using the CockroftGault formula. From 82 patients, 52 patients (62.2\%) were female, 74 patients $(90.2 \%)$ were more than 45 years old. Patients who consumed OHM for more than 2 years were 47 (57.3\%). Patients without comorbidities were 62 (75.7\%) people. Patients who experienced a decrease in GFR in the moderate category (stage 3) as many as 24 people (29.3\%), a decrease in GFR in the severe category (stage 4) as many as 5 people (6.1\%) and 1 person (1.2\%) experienced End Stage Renal Disease.
\end{abstract}

Keywords : Glomerulus Filtration Rate, DM Type II, JKN Participants

\section{PENDAHULUAN}

Diabetes Melitus (DM) merupakan suatu kelompok penyakit metabolik dengan karakteristik hiperglikemia yang terjadi karena kelainan sekresi insulin, kerja insulin, atau keduanya (Marathe et al., 2017). Jumlah penderita DM terus mengalami 153 peningkatan setiap tahunnya, terutama DM tipe 2. Menurut hasil Riskesdas 2018, prevalensi DM mengalami kenaikan dari $6,9 \%$ menjadi $8,5 \%$ (Kemenkes RI, 2018).

Pasien DM mendapat terapi obat hipoglikemik oral (OHO) dalam jangka https://doi.org/10.33759/jrki.v3i3.179 
waktu yang relative lama. Pemakaian OHO dalam jangka waktu yang relative lama akan berpengaruh terhadap fungsi ginjal, yang disebut dengan nefropati diabetik. Hal ini disebabkan karena adanya efek samping dari $\mathrm{OHO}$, pemilihan jenis OHO yang kurang tepat, serta ketidaktepatan dosis $\mathrm{OHO}$ yang diberikan (Pandanwangi et al., 2018). Nefropati diabetik merupakan suatu sindrom klinik yang terjadi pada penderita DM yang ditandai dengan keadaan uremia dan mikroalbuminuria. Penderita DM yang mengalami mikroalbuminuria akan menimbulkan uremia yang akhirnya menyebabkan kadar ureum dalam darah meningkat (Rivandi \& Yonata, 2015).

Salah satu pemeriksaan yang dilakukan untuk mengetahui fungsi ginjal adalah pemeriksaan kreatinin yang dilakukan minimal satu tahun sekali. Kreatinin merupakan hasil pemecahan kreatin fosfat otot, diproduksi oleh tubuh secara konstan tergantung massa otot. Kadar kreatinin berhubungan dengan massa otot, menggambarkan perubahan kreatinin dan fungsi ginjal (Kee, 2014). Kadar kreatinin pada orang dewasa berkisar antara $0,7-1,3 \mathrm{mg} / \mathrm{dL}$ untuk pria dan
0,6-1,1 mg/dL untuk wanita (Alfonso et al., 2016).

Kadar kreatinin serum sudah banyak digunakan untuk mengukur fungsi ginjal melalui pengukuran laju filtrasi glomerulus (LFG). Kreatinin merupakan zat yang ideal untuk mengukur fungsi ginjal karena merupakan produk hasil metabolisme tubuh yang diproduksi secara konstan, difiltrasi oleh ginjal, tidak direabsorbsi, dan disekresikan oleh tubulus proksimal (Verdiansyah, 2016). Apabila nilai LFG mengalami penurunan maka kadar kreatinin meningkat sehingga dapat dikatakan terjadi penurunan fungsi ginjal (Botev et al, 2011).

Salah satu rumah sakit swasta di Kabupaten Demak ini merupakan salah satu fasilitas kesehatan tingkat lanjut yang bekerja sama dengan Badan Penyelenggara Jaminan Sosial (BPJS) Kesehatan sebagai tempat rujukan untuk pelayanan pasien peserta JKN. Pasien DM Tipe II yang dirujuk ke rumah sakit ini menempati urutan teratas dari 10 besar penyakit. Berdasarkan latar belakang tersebut, perlu dilakukan penelitian untuk mengetahui LFG pasien DM Tipe II di salah satu rumah sakit swasta di Kabupaten Demak, 


\section{METODE PENELITIAN}

Penelitian ini merupakan penelitian deskriptif observasional menggunakan data retrospektif yang diperoleh dari data rekam medis $(\mathrm{RM})$ pasien rawat jalan peserta JKN dengan DM tipe 2 periode Oktober-Desember 2020. Kriteria inklusinya adalah pasien yang mendapat terapi $\mathrm{OHO}$ minimal satu tahun dengan atau tanpa penyakit penyerta, berumur 36 - 65 tahun, dan mempunyai pemeriksaan serum kreatinin. Pasien yang mendapat terapi kombinasi dengan insulin di ekslusi. LFG dihitung menggunakan rumus dari Cockroft-Gault (Verdiansyah, 2016).

$\mathrm{LFG}=\left\{((140-\right.$ umur $) \times$ berat badan $\left.) /\left(72 \mathrm{xS}_{\mathrm{Cr}}\right)\right\} \times 0.85$ (if female $)$

$$
\begin{array}{ll}
\text { LFG } & =\text { Laju Filtrasi Glomerulus }\left(\mathrm{mL} / \mathrm{min} / 1,73 \mathrm{~m}^{2}\right) \\
\text { Umur } & =\text { Tahun } \\
\text { Berat badan } & =\text { Kilogram } \\
\mathrm{S}_{\mathrm{Cr}}(\text { serum creatinine }) & =\mathrm{mg} / \mathrm{dL}
\end{array}
$$

Nilai LFG hasil perhitungan kemudian dikategorikan sebagai berikut :

LFG $\geq 90 \mathrm{~mL} / \mathrm{min} / 1,73 \mathrm{~m}^{2}$ maka disebut stage 1 (normal),

LFG $60-89 \mathrm{~mL} / \mathrm{min} / 1,73 \mathrm{~m}^{2}$ disebut stage 2 (penurunan fungsi ginjal ringan),

LFG $30-59 \mathrm{~mL} / \mathrm{min} / 1,73 \mathrm{~m}^{2}$ disebut stage 3 (penurunan fungsi ginjal sedang),

LFG $15-29 \mathrm{~mL} / \mathrm{min} / 1,73 \mathrm{~m}^{2}$ disebut stage 4 (penurunan fungsi ginjal berat) dan bila LFG $<15 \mathrm{~mL} / \mathrm{min} / 1,73 \mathrm{~m}^{2}$ disebut stage 5 atau End Stage Renal Disease.

\section{HASIL DAN PEMBAHASAN}

Berdasarkan hasil penelusuran data rekam medis diperoleh sebanyak 82 pasien rawat jalan dengan DM tipe II peserta JKN yang mendapat terapi OHO di rumah sakit swasta di Kabupaten Demak pada periode Oktober-Desember
2020 yang memenuhi kriteria inklusi dan ekslusi. Karakteristik pasien DM Tipe II peserta JKN yang mendapat terapi $\mathrm{OHO}$ pada periode OktoberDesember 2020 di salah satu rumah sakit swasta di Kabupaten Demak dapat dilihat pada Tabel I. 
Tabel I. Karakteristik pasien DM Tipe II peserta JKN yang mendapat terapi OHO periode Oktober-Desember 2020 di salah satu rumah sakit swasta di Kabupaten Demak

\begin{tabular}{lcc}
\hline \multicolumn{1}{c}{ Karakteristik } & Jumlah Pasien & Persentase (\%) \\
\hline Jenis Kelamin & 51 & 62,2 \\
Perempuan & 31 & 37,8 \\
Laki-laki & & \\
Umur (tahun) & 8 & 9,8 \\
$36-45$ & 36 & 43,9 \\
$46-55$ & 38 & 46,3 \\
$56-65$ & & \\
Lama menggunakan OHO (tahun) & 35 & 42,7 \\
1 & 27 & 32,9 \\
2 & 13 & 15,9 \\
3 & 7 & 8,5 \\
4 & & \\
Jumlah OHO yang digunakan & 16 & 19,6 \\
1 & 57 & 69,4 \\
2 & 9 & 11,0 \\
3 & & \\
Penyakit penyerta & 62 & 75,7 \\
Tanpa penyakit penyerta & 20 & 24,3 \\
Dengan penyakit penyerta & & \\
\hline
\end{tabular}

Berdasarkan Tabel I diketahui sebanyak 51 pasien $(62,2 \%)$ berjenis kelamin perempuan. Perbedaan komposisi lemak, resistensi insulin, dan kadar glukosa darah antara laki-laki dan perempuan, dipengaruhi oleh efek dari hormon seksual (Yulianti et al., 2014). Perempuan cenderung lebih berisiko mengalami DM Tipe II karena mempunyai jumlah lemak yang lebih tinggi dan sindrom siklus haid serta menopause yang mengakibatkan mudah menumpuknya lemak sehingga pengangkutan glukosa kedalam sel menjadi terhambat (Mildawati et al., 2019).

Sebagian besar pasien berumur $>45$ tahun yaitu sebanyak 74 orang (90,2\%). Umur merupakan faktor risiko terhadap DM Tipe 2. Umur $>45$ tahun mempunyai risiko terjadinya DM Tipe 2 semakin besar (ADA, 2015). Hal ini disebabkan karena peningkatan umur menyebabkan perubahan metabolisme karbohidrat dan perubahan pelepasan insulin yang dipengaruhi oleh glukosa dalam darah dan terhambatnya pelepasan glukosa yang masuk kedalam sel.

https://doi.org/10.33759/jrki.v3i3.179 
Berdasarkan lama penggunaan OHO, diketahui sebanyak 47 pasien menggunakan $\mathrm{OHO}$ selama 2 tahun atau lebih. Semakin lama penggunaan $\mathrm{OHO}$, jumlah pasien berkurang. Hal ini berhubungan dengan tingkat kepatuhan pasien untuk mengkonsumsi obat. Ketidakpatuhan pasien minum $\mathrm{OHO}$ dapat mengakibatkan gula darah menjadi tidak terkontrol sehingga meningkatkan terjadinya komplikasi yang berakibat pada kematian (Nanda et al., 2018).

Sebagian besar pasien $(80,4 \%)$ menggunakan $\mathrm{OHO}$ kombinasi (2-3 obat). Semakin banyak $\mathrm{OHO}$ yang digunakan maka risiko terhadap penurunan fungsi ginjal yang ditunjukkan dengan penurunan nilai LFG semakin besar. Hal ini disebabkan karena sebagian besar OHO di ekskresi melalui ginjal. Pasien tanpa penyakit penyerta dalam penelitian ini jumlahnya lebih banyak yaitu 75,7\%. Adanya penyakit penyerta akan menambah jumlah obat yang digunakan sehingga akan memperberat kerja ginjal sehingga risiko penurunan LFG yang menggambarkan penurunan fungsi ginjal juga semakin besar.

Tabel II. Laju filtrasi glomerulus pasien DM Tipe II peserta JKN dan penggunaan OHO di salah satu rumah sakit swasta di Kabupaten Demak

\begin{tabular}{|c|c|c|c|c|c|c|c|c|c|c|}
\hline \multirow{2}{*}{ Stage } & \multirow{2}{*}{$\begin{array}{c}\text { LFG } \\
\left(\mathrm{mL} / \mathrm{min} / \mathbf{1}, \mathbf{7 3 m ^ { 2 }}\right)\end{array}$} & \multicolumn{4}{|c|}{$\begin{array}{c}\text { Lama penggunaan } \\
\text { OHO (tahun) }\end{array}$} & \multicolumn{3}{|c|}{ Jumlah OHO } & \multirow{2}{*}{$\begin{array}{l}\text { Jumlah } \\
\text { pasien }\end{array}$} & \multirow{2}{*}{$\begin{array}{c}\text { Persentase } \\
\quad(\%)\end{array}$} \\
\hline & & 1 & 2 & 3 & 4 & 1 & 2 & 3 & & \\
\hline 1 & $\geq 90$ & 15 & 5 & 1 & 2 & 11 & 10 & 2 & 23 & 28 \\
\hline 2 & $60-89$ & 13 & 12 & 4 & 0 & 9 & 18 & 2 & 29 & 35,4 \\
\hline 3 & $30-59$ & 7 & 10 & 4 & 3 & 5 & 16 & 3 & 24 & 29,3 \\
\hline 4 & $15-29$ & 0 & 0 & 3 & 2 & 0 & 2 & 3 & 5 & 6,1 \\
\hline 5 & $<15$ & 0 & 0 & 1 & 0 & 0 & 1 & 0 & 1 & 1,2 \\
\hline & Total & 35 & 27 & 13 & 7 & 25 & 47 & 10 & 82 & 100 \\
\hline
\end{tabular}

Berdasarkan Tabel II diketahui bahwa pasien yang mengalami penurunan LFG paling banyak pada stage 3 atau kategori sedang yaitu 24 orang (29,3\%) dengan lama penggunaan OHO selama 2 tahun atau lebih sebanyak 17 orang, dan penggunaan
OHO kombinasi sebanyak 19 orang. Sedangkan pasien yang mengalami penurunan LFG kategori berat sebanyak 5 orang $(6,1 \%)$ dengan lama penggunaan $\mathrm{OHO}$ selama 3 tahun atau lebih dan semuanya menggunakan kombinasi OHO. Ada 1 pasien yang https://doi.org/10.33759/jrki.v3i3.179 
mengalami penurunan LFG kategori ESRD setelah menggunakan $\mathrm{OHO}$ kombinasi selama 3 tahun.

Pada pasien DM Tipe 2 di Indonesia, $\mathrm{OHO}$ yang paling banyak digunakan adalah $\mathrm{OHO}$ golongan biguanid dan sulfonilurea, hal ini karena ketersediaannya yang luas, harganya yang murah, dan ditanggung oleh jaminan kesehatan nasional (Perkeni, 2015 ; Soewondo et al., 2010). OHO yang tersedia di Indonesia meliputi metformin, sulfonilurea, tiazolidindion, glinid, penghambat glikosidase alfa, penghambat DPP-IV, dan penghambat SGLT-2 (Perkeni, 2015).

Sebagian besar $\mathrm{OHO}$ tersebut diekskresikan melalui ginjal sehingga dapat mempengaruhi fungsi ginjal. Metformin meskipun tidak dimetabolisme di hepar tetapi di ekskresi melalui ginjal (Triplitt et al., 2008). Golongan sulfonylurea seperti gliklazid juga dieliminasi melalui ginjal (Ioannidis, 2014). Penggunaan golongan tiazolidindion seperti pioglitazon juga dapat memperburuk fungsi ginjal (Schneider et al., 2008). Penghambat glikosidase alfa, seperti acarbose, walaupun bekerja lokal di usus, namun ada sebagian yang diserap dan diekskresikan melalui ginjal
(Arnouts et al., 2014). Golongan penghambat DPP-4 di Indonesia, juga di eliminasi melalui ginjal kecuali linagliptin yang diekskresi melalui system billier (Ioannidis, 2014).

Penggunaan $\mathrm{OHO}$ dalam jumlah banyak dan dalam waktu lama akan menyebabkan penurunan fungsi ginjal yang ditandai dengan menurunnya laju filtrasi glomerulus. Selain itu penurunan laju filtrasi glomerulus juga dipengaruhi oleh umur. Semakin bertambah umur, mengkonsumsi obat dalam jumlah banyak dan dalam waktu yang lama akan semakin menurunkan laju filtrasi glomerulus (Oktaviani et al.,2017; Shargel et al., 2012).

\section{KESIMPULAN}

Kesimpulan dari penelitian ini adalah :

Laju Filtrasi Glomerulus pasien DM Tipe 2 yang mendapat terapi $\mathrm{OHO}$ di salah satu rumah sakit swasta di Kabupaten Demak yang mengalami penurunan LFG kategori sedang (stage 3) sebanyak 24 orang (29,3\%), penurunan LFG kategori berat (stage 4) sebanyak 5 orang $(6,1 \%)$ dan 1 orang (1,2\%) mengalami End Stage Renal Disease.

https://doi.org/10.33759/jrki.v3i3.179 


\section{UCAPAN TERIMAKASIH}

Kami mengucapkan terimakasih kepada

Direktur Politeknik Katolik

Mangunwijaya Semarang.

\section{DAFTAR PUSTAKA}

Alfonso, A. A., Mongan, A. E., \& Memah, M. F. (2016). Gambaran kadar kreatinin serum pada pasien penyakit ginjal kronik stadium 5 non dialisis. Jurnal E-Biomedik. https://doi.org/10.35790/ebm.4.1.2 $\underline{016.10862}$

American Diabetic Association. (2015).

Standard of Medical Care in

Diabetes. Diabetic Medicine, 24, 451-463.

Arnouts P, Bolignano D, Nistor I, Bilo H, Gnudi L, Heaf J, et al. (2014). Glucose-lowering drugs in patients with chronic kidney disease: a narrative review on pharmacokinetic properties. Nephrol Dial Transplant, 29, 1284-300.

Botev, R., Mallie, J. P., Wetzels, J. F. M., Couchoud, C., \& Schück, O. (2011). The clinician and estimation of glomerular filtration rate by creatinine-based formulas:
Current limitations and Quo vadis. Clinical Journal of the American Society of Nephrology. 6(4):937950.

https://doi.org/10.2215/CJN.09241 $\underline{010}$

Ioannidis I. (2014). Diabetes treatment in patients with renal disease: Is the landscape clear enough? World J Diabetes. 5(5), 651-8.

Kee, J. le F. (2014). Pedoman pemeriksaan laboratorium \& diagnostic. In EGC. Jakarta.

Kemenkes RI. (2018). Hasil Utama Riskesdas Tentang Prevalensi Diabetes Mellitus di Indonesia 2018.

Marathe, P. H., Gao, H. X., \& Close, K. L. (2017). American Diabetes Association Standards of Medical Care in Diabetes 2017. In Journal of diabetes, 9, 320-324. https://doi.org/10.1111/1753-

\section{$\underline{0407.12524}$}

Mildawati, Mildawati., Diani, Noor., Wahid, Abdurrahman. Hubungan Usia, Jenis Kelamin dan Lama Menderita Diabetes dengan Kejadian Neuropati Perifer Diabetik. CNJ: Caring Nursing https://doi.org/10.33759/jrki.v3i3.179 
Journal, [S.1.], 3 (2), 30-37,

https://journal.umbjm.ac.id/index.p hp/caring-nursing/article/view/238

Nanda, O. D., Wiryanto, B., \& Triyono, E. A. (2018). Hubungan Kepatuhan Minum Obat Anti Diabetik dengan Regulasi Kadar Gula Darah pada Pasien Perempuan Diabetes Mellitus. Amerta Nutrition. 340-348. https://doi.org/10.20473/amnt.v2i4. $\underline{2018.340-348}$

Oktaviani, Emy., Wahyono, Djoko., Probosusesno. (2017). Evaluasi Penggunaan Antidiabetik Oral Pada Pasien DM Tipe 2 dengan Gangguan Fungsi Ginjal Rawat Jalan di RSUP dr.Sardjito Yogyakarta, Rapat Pleno APTFI dan Seminar Nasional. https://repository.unpak.ac.id/tukan gna/repo/file/files-

20180630170228.pdf

Pandanwangi, S., Zuniarto, A. A., \& Mubarok, H. (2018). Analisa Drug Related Problems (DRPS) Pasien Gagal Ginjal Dengan Komplikasi Diabetes Mellitus Di RSUD X. Pharma Xplore: Jurnal Ilmiah Farmasi., 3

https://doi.org/10.36805/farmasi.v3

\section{$\underline{11.330}$}

PB Perkeni. (2015). Konsensus pengelolaan dan pencegahan diabetes melitus tipe 2 di Indonesia. Jakarta: PB Perkeni.

Rivandi, J., \& Yonata, A. (2015). Hubungan Diabetes Melitus Dengan Kejadian Gagal Ginjal Kronik. Jurnal Majority, 4(9), 2734.

Schneider CA, Ferrannini E, DeFronzo R, Schernthaer, Yates J, Erdmann E. (2008). Effect of pioglitazone on cardiovascular ourcome in diabetes and chronic kidney disease. J Am Soc Nephrol, 19(1), 182-7.

Shargel, L., Susanna, W.P., Andrew, B.C.Y. (2012). Biofarmasetika dan Farmakokinetika Terapan, Ed. Kelima, Pusat Penerbitan dan Percetakan Universitas Airlangga Surabaya.

Soewondo P, Soegondo S, Suastika K, Soeatmadji DW. (2010). The DiabCare Asia 2008 studyoutcomes on control aand complications of type 2 diabetic patients in Indonesia. MJI, 19(3), 234-44.

https://doi.org/10.33759/jrki.v3i3.179 
Triplitt, C. L., Reasner, C. A. \& Isley, W. L. (2015). Endocrinologic Disorders: Diabetes Mellitus, Editor: Dipiro, T. J., Talbert, R. L., Yee, G. C., Matzke, G. R., Wells, B. G. \& Posey, L. M.,
Pharmacotheraphy Handbook, 9th edition, McGraw-Hill, New York Verdiansyah. (2016). Pemeriksaan Fungsi Ginjal. CDK : Cermin Dunia Kedokteran, 43 (2) : 148154. 